\title{
TWO PARAMETRIC FUNCTIONAL DEPENDENTS OF TIME FOR CONSTRUCTION OF HORIZONTAL MINING FACILITIES IN GNEISS AND SCHIST
}

\author{
Nikolinka Doneva ${ }^{1}$, Zoran Despodov ${ }^{1}$, Dejan Mirakovski ${ }^{1}$, Marija Hadzi- \\ Nikolova $^{1}$, Stojanče Mijalkovski ${ }^{1}$
}

Received: April 15, 2019

Accepted: June 8, 2019

\begin{abstract}
This paper presents the analysis of the construction of horizontal mining facilities where 18 variants of mining facilities were developed. The aim of this research was to determine the required time for construction of all variants and then to reduce it to the time required for construction of $1 \mathrm{~m}$ ' per facilities. Also the required time for construction of $1000 \mathrm{~m}$ ' of the same facilities is calculated. Based on analysis, two parametric functional dependents of construction time are determined in relation of uniaxial compressive strength of rock mass and the size of the facilities`cross section.
\end{abstract}

Keywords: uniaxial compressive strength; cross-section area; rock bolts; mesh; sprayed concrete;

\section{INTRODUCTION}

The process of underground mining facilities construction is very important for underground exploitation of mineral resources. Namely, the construction costs for primary mining facilities occupy $40-60 \%$ of underlying investments during construction and equipping of mine. The underground mining facilities construction, including horizontal mining premises, presents a complex system dependent on many elements. Practical experience has shown the fact that the type of working environment directly affects the manner of working operations (Doneva et al., 2012a; Doneva et al., 2012b) and the duration thereof.

\footnotetext{
${ }^{1}$ Faculty of natural and technical science, Goce Delchev University, Stip, Macedonia Emails:nikolinka.doneva@ugd.edu.mk;zoran.despodov@ugd.edu.mk;dejan.mirakovski@ugd.edu.m k; marija.hadzi-nikolova@ugd.edu.mk; stojance.mijalkovski@ugd.edu.mk
} 


\section{DEVELOPING VARIANTS IN MATHEMATICAL MODEL}

Below are given the rock types in which the mining facility construction will be performed:

- gneiss and

- $\quad$ schist

Table 1 shows physical and mechanical properties obtained by laboratory tests that are required for this survey as follows: bulk density $\gamma\left[\mathrm{MN} / \mathrm{m}^{3}\right]$, uniaxial compressive strength $\sigma_{\mathrm{c}}[\mathrm{MPa}]$, tensile strength $\sigma_{\mathrm{t}}[\mathrm{MPa}]$, cohesion $\mathrm{C}[\mathrm{MPa}]$, angle of internal friction $\varphi\left[^{\circ}\right]$, Poisson`s coefficient $v$ and modulus of elasticity E [MPa].

Table 1 Physical and mechanical characteristics of the anticipated rocks type

\begin{tabular}{cccccccc}
\hline $\begin{array}{c}\text { Anticipated } \\
\text { rock type }\end{array}$ & $\gamma$ & $\sigma_{\mathrm{C}}$ & $\sigma_{\tau}$ & $\mathrm{C}$ & $\varphi$ & $\nu$ & $\mathrm{E}$ \\
\hline Gneiss & 0.0275 & 127 & 14.5 & 20.5 & 37.5 & 0.17 & 42000 \\
Schist & 0.027 & 98 & 6.1 & 14 & 32 & 0.12 & 32000 \\
\hline
\end{tabular}

Depending on cracking extent, three quasi homogeneous zones are determined in any working environment. For each of them uniaxial compressive strength is calculated using the following form (Doneva et al., 2013; Milanovic and Torbica, 1997):

$$
\frac{\sigma_{c m}}{\sigma_{c}}=e^{-0,008 \cdot J_{f}},[M P a]
$$

where:

$$
\begin{aligned}
& \sigma_{c m} \text { - uniaxial compressive strength of rock mass, [MPa]; } \\
& \sigma_{c} \text { - uniaxial compressive strength of intact rock material, [MPa]; } \\
& J_{f} \text { - factor of cracks (considers cracking and cracks incline). }
\end{aligned}
$$


The paper examined three variants with different sizes of facilities cross-section.

The following table presents variants, sub - variants of horizontal mining facilities developed in accordance with the working environment, then its cracking extent and the cross section size (Doneva, 2011).

Table 2 Variants and sub - variants in the models

\begin{tabular}{|c|c|c|c|c|}
\hline Rock type & $\begin{array}{c}\text { Tag of } \\
\text { variants in } \\
\text { the model }\end{array}$ & $\begin{array}{c}\text { Uniaxial } \\
\text { compressive strength } \\
\text { of intact rock } \\
\sigma_{\mathrm{c}}[\mathrm{MPa}]\end{array}$ & $\begin{array}{l}\text { Tag of sub - } \\
\text { variants in } \\
\text { the models }\end{array}$ & $\begin{array}{c}\text { Cross- } \\
\text { section area } \\
\mathrm{S}\left[\mathrm{m}^{2}\right]\end{array}$ \\
\hline \multirow{9}{*}{ Gneiss } & \multirow{3}{*}{ A1 } & \multirow{3}{*}{80} & $\mathrm{~A} 1 / 1$ & 10.1 \\
\hline & & & $\mathrm{A} 1 / 2$ & 13.73 \\
\hline & & & $\mathrm{A} 1 / 3$ & 16.68 \\
\hline & \multirow{3}{*}{ A2 } & \multirow{3}{*}{70} & A2/1 & 10.1 \\
\hline & & & $\mathrm{A} 2 / 2$ & 13.73 \\
\hline & & & $\mathrm{A} 2 / 3$ & 16.68 \\
\hline & \multirow{3}{*}{ A3 } & \multirow{3}{*}{63} & $\mathrm{~A} 3 / 1$ & 10.1 \\
\hline & & & $\mathrm{A} 3 / 2$ & 13.73 \\
\hline & & & $\mathrm{A} 3 / 3$ & 16.68 \\
\hline \multirow{9}{*}{ Schist } & \multirow{3}{*}{ B1 } & \multirow{3}{*}{52} & B1/1 & 10.1 \\
\hline & & & $\mathrm{B} 1 / 2$ & 13.73 \\
\hline & & & $\mathrm{B} 1 / 3$ & 16.68 \\
\hline & \multirow{3}{*}{ B2 } & \multirow{3}{*}{42} & B2/1 & 10.1 \\
\hline & & & $\mathrm{B} 2 / 2$ & 13.73 \\
\hline & & & $\mathrm{B} 2 / 3$ & 16.68 \\
\hline & \multirow{3}{*}{ B3 } & \multirow{3}{*}{35} & B3/1 & 10.1 \\
\hline & & & $\mathrm{B} 3 / 2$ & 13.73 \\
\hline & & & $\mathrm{B} 3 / 3$ & 16.68 \\
\hline
\end{tabular}

To obtain data that can be compared, other influential parameters in the mining construction system are needed to be the same in all mining facilities (Doneva, 2011).

Construction system includes these fixed parameters:

- cross-sectional shape of the mining facilities - horse - shoe shaped;

- the average depth of the same route - $500 \mathrm{~m}$;

- usage of the mining facility - relatively long;

- mechanization level of the production process - relatively equally; 
- method for excavation of the mining facilities - drilling and blasting operations;

- capability of working personnel - relatively well trained;

- one shift duration and number of shifts per day - 6 effective hours per shift and 3 shifts per day were applied in the calculations.

\section{PARAMETERS OF SEPARATE WORKING OPERATIONS}

In all variants, blasting holes with $45 \mathrm{~mm}$ diameter and $2.7 \mathrm{~m}$ length were applied. Advance length for one blasting is $2.3 \mathrm{~m}$.

Prismatic cut type with empty central hole was applied. Explosive AMONEKS-3, produced by "Trayal" Corporation of Krusevac, Serbia was used for blasting. Cartridges with $38 \mathrm{~mm}$ diameter are used for auxiliary and cut holes, while for flanking blast holes, cartridges with $28 \mathrm{~mm}$ diameter (smooth blasting). Calculations for required time, drilling and blasting parameters are performed using same formulas and reviewed by experienced data (for all working operations and all variants).

After drilling and blasting, a break of 30 minutes follows (adopted time for all variants) when compression LVS (local ventilation system) is used for releasing the dust from the workplace and harmful gasses from the blasting.

Diesel mechanization, combination of LDH machines and mine trucks, will be used for loading and transportation. For all drifts variants under consideration, average transport distance of $800 \mathrm{~m}$ for underground trucks and $100 \mathrm{~m}$ for the LHD machines is adopted because reloading chambers are proposed on every $200 \mathrm{~m}$.

Elastic support will be applied (sprayed concrete + steel mesh + bolts + steel ribs). The presence of individual support elements depends on calculations for required support loads, bearing in mind rock type features (Cummings, 1982; Jovanovic, 1994).

Based on a previously established methodology, the time for any working operation is calculated using empirical formulas and experience data from the lead and zinc mine "Sasa", M.Kamenica.

\section{TIME REQUIRED FOR CONSTRUCTION ON 1 m' OF EACH HORIZONTAL MINING FACILITIES' VARIANTS}

For each variant, operating parameters for each working operation are determined, as well as the time required for their execution. The calculated time to perform basic working operations, and the total construction time of all variants in mathematical model are presented in Table 3. 
Two parametric functional dependents...

Table 3 Total time for all basic work operations and total construction time

\begin{tabular}{|c|c|c|c|c|c|c|}
\hline $\begin{array}{c}\text { Tag of } \\
\text { sub - } \\
\text { variants } \\
\text { in the } \\
\text { models }\end{array}$ & $\begin{array}{c}\text { Total time } \\
\text { for drilling } \\
\text { and } \\
\text { blasting } \\
\text { per m' } \\
\text { drift } \\
{\left[\mathrm{h} / \mathrm{m}^{\prime}\right]}\end{array}$ & $\begin{array}{c}\text { Total time } \\
\text { for } \\
\text { ventilation } \\
\text { per m' } \\
\text { drift } \\
{\left[\mathrm{h} / \mathrm{m}^{\prime}\right]}\end{array}$ & $\begin{array}{c}\text { Total time } \\
\text { for loading } \\
\text { and hauling } \\
\text { per } 1 \mathrm{~m} \text { ' } \\
\text { drift } \\
{\left[\mathrm{h} / \mathrm{m}^{\prime}\right]}\end{array}$ & $\begin{array}{l}\text { Total time } \\
\text { for } \\
\text { supporting } \\
\text { per } 1 \mathrm{~m} \\
\text { drift } \\
{\left[\mathrm{h} / \mathrm{m}^{\prime}\right]}\end{array}$ & $\begin{array}{c}\text { Total } \\
\text { construction } \\
\text { time per } \\
1 \mathrm{~m} \text { ' drift } \\
{[\mathrm{h}]}\end{array}$ & $\begin{array}{c}\text { Total } \\
\text { construction } \\
\text { time per } \\
1000 \mathrm{~m} \\
\text { drift } \\
\text { [days] }\end{array}$ \\
\hline $\mathrm{A} 1 / 1$ & 1.77 & 0.22 & 1.22 & 1.50 & 4.71 & 262 \\
\hline $\mathrm{A} 1 / 2$ & 1.94 & 0.22 & 1.30 & 1.60 & 5.06 & 281 \\
\hline $\mathrm{A} 1 / 3$ & 2.24 & 0.22 & 0.91 & 1.70 & 5.07 & 282 \\
\hline $\mathrm{A} 2 / 1$ & 1.77 & 0.22 & 1.22 & 1.50 & 4.71 & 262 \\
\hline $\mathrm{A} 2 / 2$ & 1.94 & 0.22 & 1.30 & 1.70 & 5.16 & 287 \\
\hline $\mathrm{A} 2 / 3$ & 2.17 & 0.22 & 0.91 & 1.80 & 5.10 & 283 \\
\hline $\mathrm{A} 3 / 1$ & 1.69 & 0.22 & 1.22 & 1.60 & 4.73 & 263 \\
\hline $\mathrm{A} 3 / 2$ & 1.90 & 0.22 & 1.30 & 1.70 & 5.12 & 284 \\
\hline A $3 / 3$ & 2.11 & 0.22 & 0.91 & 1.90 & 5.14 & 286 \\
\hline B1/1 & 1.31 & 0.22 & 1.04 & 4.70 & 7.27 & 404 \\
\hline $\mathrm{B} 1 / 2$ & 1.38 & 0.22 & 1.08 & 5.00 & 7.68 & 427 \\
\hline $\mathrm{B} 1 / 3$ & 1.63 & 0.22 & 0.78 & 5.20 & 7.83 & 435 \\
\hline B2/1 & 1.31 & 0.22 & 1.04 & 4.90 & 7.47 & 415 \\
\hline B2/2 & 1.38 & 0.22 & 1.08 & 5.10 & 7.78 & 432 \\
\hline B2/3 & 1.63 & 0.22 & 0.78 & 5.30 & 7.93 & 441 \\
\hline B3/1 & 1.28 & 0.22 & 1.04 & 5.10 & 7.64 & 424 \\
\hline $\mathrm{B} 3 / 2$ & 1.38 & 0.22 & 1.08 & 5.40 & 8.08 & 449 \\
\hline $\mathrm{B} 3 / 3$ & 1.63 & 0.22 & 0.78 & 5.70 & 8.33 & 463 \\
\hline
\end{tabular}

The analysis of drilling and blasting time, given in Table 3 , shows that the drilling and blasting time is highest in the strongest working environment, gneiss.

The drilling and blasting time is decreased because of the smaller requirements of weaker working environment, in terms of this working operation i.e. the number of needed holes is lower. Within the same working environment drilling and blasting time grow up with the profile size growth, so at the biggest profile size they are 16-20\% higher (depending on working environment) than the ones with the smallest profile. The time is increased because of profile size increases i.e. number of blast holes and length of drilling.

As it has been said, after blasting in all variants time ventilation is adopted on $30 \mathrm{~min}$. In Table 3 this time is reduced to the time needed for construction of $1 \mathrm{~m}$ ' mining facility $\left(0.22 \mathrm{~h} / \mathrm{m}^{\prime}\right)$.

Table 3 shows that the time for loading and hauling is relatively uniform at all variants. Going from a working environment A to B for the same cross section size the time has a slight decrease, because the density is largest at gneiss and smaller at schist, which affects the number of cycles required for the loading and hauling machinery. 
Time analysis at the same variant shows an increasing of time at profile 2 rather than time at profile 1 because of larger cross-section as well as larger amount of blasted material. The percentage of time increasing amounts are 4-7 \% (depending on working environment).

Some deviation occurs at profile "3" where the time of loading and transport are decreased again, even though the amount of material that must be transported is higher, due to considerably higher loads of the adopted loading and transport machinery. This is possible due to the larger cross section.

Table 3 shows that the biggest time variations occur at supporting due to large differences in applied supporting construction. For variants in a working environment A, the supporting construction includes sprayed concrete, rock bolts and wire mesh.

The working environment B has the extensive support system construction and consists of sprayed concrete, bolts, wire mesh and steel arches because of its weakest strength features. Supporting time is 3 times larger in the weakest (B) working environment than the ones at the strongest (A) working environment for the same cross section.

Supporting time is increased in the same working environment due to increasing crosssection. So the time at the largest cross section - 3 , is $10 \%$ larger (in working environment - schist) than the costs in cross-section 1(Doneva et al., 2015).

\section{FUNCTIONAL DEPENDENCE}

Based on calculated construction time required for horizontal mining facilities (18 variants), using a computer program OM Explorer an upgrade on the Excel program a functional dependence at the construction time from the rock type and the profile size were established in the following form (Doneva et al., 2012a):

$$
z=c+a x+b y
$$

Where:

$\mathrm{x}$ - uniaxial compressive strength of rock mass [MPa];

$\mathrm{y}$ - profile size of facility $\left[\mathrm{m}^{2}\right]$, (independent variables)

$\mathrm{z}$ - required time for construction of $1000 \mathrm{~m}$ ' per horizontal mining facility

[days], (dependent variable)

c-constant;

$\mathrm{a}, \mathrm{b}-$ constants before independent variables.

Following values of coefficients are obtained:

Working environment , $A$ “": gneiss

$$
\begin{aligned}
& c=243.002 \\
& a=-0.162 \\
& b=3.345
\end{aligned}
$$

$$
z=243.002-0.162 x+3.345 y
$$


This functional dependence is graphically presented on Figure 1a.

\section{Working environment „B“: schist}

$$
\begin{aligned}
& c=423.124 \\
& a=-1.329 \\
& b=4.905
\end{aligned}
$$

$$
z=423.124-1.329 x+4.905 y
$$

This functional dependence is graphically presented on Figure $1 \mathrm{~b}$.

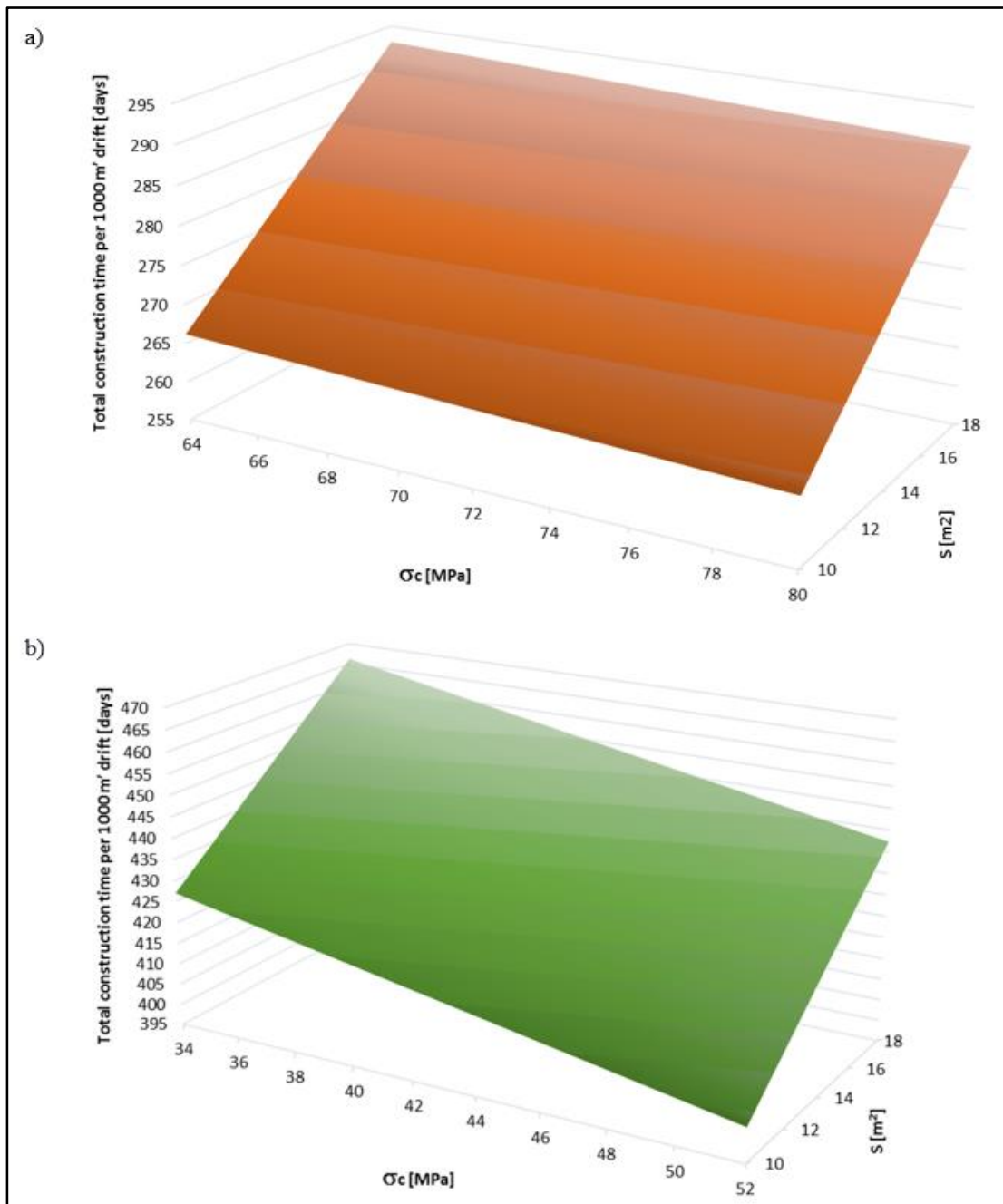

Figure 1 Functional dependence on the construction time of horizontal mining facilities depending on the rock type and profile size, a) in the rock type A; b) in the rock type B 


\section{CONCLUSIONS}

Based on the research carried out in this paper, the following can be concluded:

- Changing the type of working environment and horizontal mining facilities' profile size leads to differences in the construction time needed in individual working operations and total construction time needed;

- The time needed for construction of horizontal mining facilities increases with increasing facilities cross-section, as well as with reducing strength characteristics of the working environment through which the specified route passes;

- The identified time for all working operations shows that the time changes are more pronounced with the change of working environment than with the change of the cross-section of horizontal mining facility, which is especially pronounced at the drilling and blasting time as well as supporting time.

\section{REFERENCES}

CUMMINGS, R. A., KENDORSKI, F. S. and BRENIAWSKI, Z. T. (1984) Caving rock mass classification and support estimation. Bureau of Mines.

DONEVA, N. (2011) 'Methodology for determination of functional dependence of expenditure by rock's type and size of the profile of construction horizontal mining facilities'. Thesis (PhD), Goce Delchev University, Shtip.

DONEVA, N. et al. (2013) Rock mass classification and their usage in mining. In: Proceeding of the XIIth national conference with international participation of the open and underwater mining of minerals. Varna, Bulgaria: Scientific and Technical Union of Mining, Geology and Metallurgy, pp. 279-283.

DONEVA, N. et al. (2012a) Influence on structural characteristic of the rock material on expenditures for construction on horizontal mining facilities. Natural resources and technologies, VI (6). pp. 5-14.

DONEVA, N. et al. (2012b) The influence of the rock type on the time for the construction of horizontal facilities. Mining and geology, VIII (8), pp 12-15.

DONEVA, N. et al. (2015) Cost Analysis in the Construction of Underground Mining Structures and Opportunities for Their Reduction. The Mining-Geology-Petroleum Engineering Bulletin, 30 (2), pp. 1-12. 
JOVANOVIC, P. (1994) Design and calculation of support horizontal mining facility first book. Belgrade: University of Belgrade - Faculty of Mining and Geology.

MILANOVIC, P. and TORBICA, S. (1997) Rock mass classifications and its application. Belgrade: Belgrade: University of Belgrade - Faculty of Mining and Geology. 